International Journal of Instruction e-ISSN: 1308-1470 • www.e-iji.net

Article submission code: 20210228004017

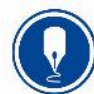

January $2022 \bullet$ Vol.15, No.1

p-ISSN: 1694-609X

pp. $733-746$

Received: 28/02/2021

Revision: 03/08/202
Accepted: $26 / 08 / 2021$

OnlineFirst: $14 / 11 / 2021$

\title{
Individual Vs. Team Based Readiness Assurance Testing in Pharmacy Calculations
}

\section{Edward C. Bell}

Texas Southern University, 3100 Cleburne Street, Houston, TX 77004, The United States of America, edward.bell@tsu.edu

Team based learning in the form of its readiness assurance test (RAT) application is a popular instructional intervention in health professions education. This investigation was conducted to examine the extent to which individual and team readiness assurance tests correlate with conventional assessment outcomes in pharmacy calculations. Students encountered IRAT and TRAT assessments on the Blackboard learning management platform during their pharmacy calculations laboratory course. The RAT assessments addressed topics concurrently with examination topics in the pharmacy calculations lecture course. Students were also assigned self-paced online module assessments pertaining to each lecture topic. Both sets of student lecture assessment scores were compared to their respective RAT performances using Spearman's rank correlation measurements. Low-tomoderate correlations were observed between students' IRAT scores and lecture course assessment scores, which includes examinations and online modules. Several correlations were statistically significant among topics. Very low-to-low correlations were observed between students' TRAT scores and lecture course assessment scores. IRAT scores better correlated to final exam performances than TRAT scores. RAT assessments, particularly IRAT, may serve as indicators of subsequent assessment performance in pharmacy calculations. Use of RAT may also assist students in their preparations for comprehensive assessments in the subject.

Keywords: assessment, pharmacy calculations, IRAT, TRAT, correlation

\section{INTRODUCTION}

The rise of active learning in education signals an acknowledgement of the importance and effectiveness of student-centered approaches to instruction. Student-centered instruction accounts for variations in student learning styles, information processing, work methods, and use of learning resources. Student-centered learning particularly flourishes in the instance of collaboration among students, which promotes increased engagement, increased confidence, and better behaviour in students (Burns et al., 2014). Student collaboration has been associated with the development and retention of critical

Citation: Bell, E. C. (2022). Individual Vs. team based readiness assurance testing in pharmacy calculations. International Journal of Instruction, 15(1), 733-746. https://doi.org/10.29333/iji.2022.15142a 
thinking skills, and has been noted to positively impact students' cognitive development, emotional awareness, motivation to learn, and receptiveness to novel ideas (Warsah et al., 2021). Collaborative learning also promotes student reflection and encourages personal assessment of strengths and weaknesses through acceptance of constructive criticism from peers (Yaacob et al., 2021). Use of the team construct in the classroom has gradually evolved as academia has gained greater appreciation of its value.

An especially well-structured form of the team construct is team-based learning (TBL), which has gained great favor in higher educational instruction, and has proven beneficial to health professions education. Team-based learning has also been touted for its faculty facilitation, its small group sizes, and its use of immediate feedback (Burgess et al., 2017). Although TBL encompasses multiple techniques of content delivery and reinforcement, a popular feature of this method is use of the readiness assurance test (RAT), which is deemed both a vehicle for rapid feedback (Bauler et al., 2020) and a motivator of student preparation (Koh et al., 2019). The RAT is distributed to individuals or to student teams. Use of RAT assessments allow students to remediate through facilitator and team feedback, and through team assessment. The RAT allows for identification of weaker performers prior to major assessment. Stronger performers are spared from sacrificing scoring opportunities for the sake of team participation, which has traditionally been a disadvantage of group work (Parmelee et al., 2012). Technology has added versatility to the RAT, as audience response systems such as iClicker $^{\mathrm{TM}}$, and web-based platforms such as Blackboard ${ }^{\mathrm{TM}}$, Moodle ${ }^{\mathrm{TM}}$, ExamSoft ${ }^{\mathrm{TM}}$ and Nearpod $^{\mathrm{TM}}$ can be used to manage and collect assessment data efficiently and rapidly (Shaikh et al., 2017).

\section{Context and Literature Review}

Team-based learning is used in the instruction of various pharmacy-related disciplines, including pathophysiology, pharmacology and medicinal chemistry. It has been favorably received among students and faculty of the basic sciences, and its use has been associated with improvements in students' content mastery (Kolluru et al., 2012). Use of TBL has also yielded equalization of pharmacotherapy learning outcomes with traditional lecture methods (Wilson et al., 2019), or improved pharmacotherapy outcomes compared to traditional methods (Letassy et al., 2008). Improvements in students' learning outcomes have also been reported in the areas of pharmacy informatics (Hincapie et al., 2016), pharmacokinetics (Persky, 2012), and pharmacy practice (Orr et al., 2015; Zingone et al., 2010).

Pharmacy calculations is a subject that covers a range of topics that are inevitably referenced in pharmacotherapy. Due to its ubiquitous presence throughout pharmacy curricula, pharmacy calculations has received renewed interest, appreciation and emphasis in recent years (Hegener et al., 2013). This revival of sorts has coincided with technology-driven, alternative methods by which students are encouraged to consume and to retain course content (Mastropieto et al., 2019; Davies et al., 2018; Bell et al., 2017; Nutan \& Demps, 2014; Lacroix et al., 2014;). Despite this renaissance, there have been few published studies featuring the use of TBL in pharmacy calculations (Mastropieto et al., 2019; Wara et al., 2019; Davies et al., 2018; Anderson et al., 2017), 
which includes even fewer references to the use of RAT during its instruction (Mastropieto et al., 2019; Wara et al., 2019). Lack of application of TBL in pharmacy calculations is counterintuitive, since the method is reported to positively impact the instruction of various math-based disciplines. For instance, TBL promotes decreased anxiety and increased confidence in collegiate math students (Naughton et al., 2020), and encourages positive active engagement among peers (Paterson et al., 2013). Use of TBL has also been shown to strengthen students' problem-solving skills and listening skills, along with their abilities to adapt, to innovate and to think independently in STEM (science, technology, engineering and math) subjects (Hashim et al., 2018). Given the effectiveness of RAT exhibited in other areas of pharmacy and in math disciplines, the applicability of the learning tool to pharmacy calculations is intriguing.

This investigation was conducted to determine the extent to which readiness assurance testing correlates with traditional learning assessments in pharmacy calculations. The investigation was performed during a single semester with 1 st year professional program students. Pharmacy calculations was offered in the form of a lecture course and an adjoining laboratory course. The lab course offered reinforcement of topics introduced during lectures. Reinforcement was provided through hands-on activities, recitation and assessment. Whereas TBL was a challenge to execute during the lecture period due to room logistics (ie., inconvenient auditorium seating) and time constraints, the lab class was a more conducive setting. Lab student groups assembled at large tables. In addition, students were enrolled into one of three lab course sections, which featured substantial time intervals for activities. Each lab section met once per week.

\section{METHOD}

Study procedures were approved via Institutional Review Board oversight. Students ( $\mathrm{n}=$ 69 ) in the pharmacy calculations lecture course were assessed using four written examinations and a stand-alone quiz. Exam 1 focused on the topics of prescription interpretation, the metric system, and intra- and inter-system unit conversion. Exam 2 focused on the topics of dosage calculations, reducing and enlarging formulas and specific gravity. Exam 3 focused on the topics of expressions of strength, dilution and concentration, and intravenous admixtures/ infusions. The topic of chemical equivalency was taught and tested upon as a quiz subsequent to the first 3 examinations. A comprehensive final examination was given at the culmination of the course. Students in the lecture course were also assigned online practice modules as graded homework. The modules were available on the Blackboard learning management system, and were released to students in conjunction with topics introduced in lecture. Module exercises were un-proctored, and were available for student use any time of day until the end of the lecture. They could be encountered with limitless repetition until students attained scores to their satisfaction. First attempt scores were recorded, and highest scores attained during each set of module attempts were incorporated into students' final grades.

Pharmacy calculations lab students formed in groups of 3 for the TBL activities. All students were exposed to all readiness assurance test interventions. Readiness assurance test activities were performed using the Blackboard learning management system, which 
provided an efficient platform for question randomization and dissemination, and for record keeping. Students were encouraged to use their personal laptops and tablets during assessments. The Respondus Lockdown Browser ${ }^{\mathrm{TM}}$ application on Blackboard was mandated for assessment access. The lockdown browser secured the assessments by disallowing students from opening other websites or personal files. Assessments were proctored using a faculty member and/or graduate teaching assistants assigned to each lab section. Readiness assurance test procedures began with a 20-minute individual readiness assurance test (IRAT). Students then retreated to their groups to take a 20minute team readiness assurance test (TRAT), which included question stems that matched those of the IRAT questions. Students were provided a brief review period after the TRAT session, during which time they were able to obtain clarification about areas of uncertainty. Students who either did not possess electronic devices or experienced technical difficulties during assessments were provided alternative paper assessments for the readiness tests. Topics encountered during IRAT and TRAT sessions matched the sequence of those presented during the pharmacy calculations lecture course. Conceptual material addressed during the weekly IRAT and TRAT included:

- IRAT/ TRAT 1-- Metric system and unit conversions

- IRAT/ TRAT 2-Dose calculations

- IRAT/ TRAT 3-Reducing and Enlarging Formulas

- IRAT/ TRAT 4-Specific gravity

- IRAT/ TRAT 5-Expressions of strength

- IRAT/ TRAT 6-Dilution and concentration

- IRAT/ TRAT 7-Infusions and IV admixtures

- IRAT/ TRAT 8-Chemical equivalency

This assessment sequence matched online modules 2 through 9.

Score data from lecture exams, homework modules, and lab RAT for all students was collected and compiled for statistical analysis. Correlations and tests for significance among score categories were determined using Excel $^{\mathrm{TM}}$ (Microsoft Corporation) software, in conjunction with XLSTAT ${ }^{\mathrm{TM}}$ (Addinsoft Inc.) and StatPlus ${ }^{\mathrm{TM}}$ (AnalystSoft Inc.) software add-ons. A threshold of $\alpha=.05$ was selected for tests of significance.

\section{FINDINGS}

Score correlations between IRAT scores and lecture course assessment scores, and between TRAT scores and lecture course assessment scores are presented in Table 1. Correlations between homework module performances and IRAT or TRAT scores are presented in Tables 2 and 3. To summarize and to contrast the interventions, average IRAT and average TRAT scores, respectively, are associated with Final Exam scores in Figures 1 and 2. 
Spearman's correlation coefficients were used due to detection of non-parametric distributions throughout data comparisons. Individual readiness assurance tests exhibited low-to-moderate $(.2<\mathrm{r}<.6)$ correlations with applicable lecture assessment scores (Table 1), all in statistically significant fashion. In contrast, team readiness assurance tests exhibited predominantly weak $(-.2<\mathrm{r}<.3)$ correlations with lecture assessment scores. Statistical significance was observed in the correlations between TRAT 1 (metric system and conversion of units) scores and both Exam $1(p<.05)$ and Final Exam scores $(p<.005$ ), and in the correlation between TRAT 5 (expressions of strength) scores and Final Exam scores $(p<.05)$.

Table 1

Correlations of IRAT and TRAT results with lecture assessment scores

\begin{tabular}{|c|c|c|c|c|c|c|}
\hline & & $\begin{array}{l}\text { Exam 1 } \\
(68 \pm 22.6)^{\#}\end{array}$ & $\begin{array}{l}\text { Exam 2 } \\
(66.1 \pm 22.0)^{\#}\end{array}$ & $\begin{array}{l}\text { Exam 3 } \\
(57.1 \pm 28.8)^{\#}\end{array}$ & $\begin{array}{l}\text { Chem. Equiv. } \\
(62.6 \pm 29.0)^{\#}\end{array}$ & $\begin{array}{l}\text { Final Exam } \\
(79.4 \pm 14.9)^{\#}\end{array}$ \\
\hline \multirow[t]{2}{*}{ Irat 1} & Correlation & .54 & & & & .41 \\
\hline & $p$-value & $<.0001 *$ & & & & $.001 *$ \\
\hline \multirow[t]{2}{*}{ Irat 2} & Correlation & & .45 & & & .42 \\
\hline & $p$-value & & $.00 *$ & & & $.00 *$ \\
\hline \multirow[t]{2}{*}{ Irat 3} & Correlation & & .32 & & & .31 \\
\hline & $p$-value & & $.008 *$ & & & $.01 *$ \\
\hline \multirow[t]{2}{*}{ Irat 4} & Correlation & & .40 & & & .39 \\
\hline & $p$-value & & $.001 *$ & & & $.001 *$ \\
\hline \multirow[t]{2}{*}{ Irat 5} & Correlation & & & .57 & & .50 \\
\hline & $p$-value & & & $<.0001 *$ & & $<.0001^{*}$ \\
\hline \multirow{2}{*}{ Irat 6} & Correlation & & & .41 & & .36 \\
\hline & $p$-value & & & $.001 *$ & & $.003 *$ \\
\hline \multirow[t]{2}{*}{ Irat 7} & Correlation & & & .28 & & .29 \\
\hline & $p$-value & & & $.02 *$ & & $.02 *$ \\
\hline \multirow[t]{2}{*}{ Irat 8} & Correlation & & & & .40 & .47 \\
\hline & $p$-value & & & & $.001 *$ & $<.0001 *$ \\
\hline \multirow[t]{2}{*}{ Trat 1} & Correlation & .25 & & & & .41 \\
\hline & $p$-value & $.04 *$ & & & & $.001 *$ \\
\hline \multirow[t]{2}{*}{ Trat 2} & Correlation & & .23 & & & .19 \\
\hline & $p$-value & & .06 & & & .12 \\
\hline \multirow[t]{2}{*}{ Trat 3} & Correlation & & -.02 & & & .02 \\
\hline & $p$-value & & .90 & & & .85 \\
\hline \multirow[t]{2}{*}{ Trat 4} & Correlation & & .15 & & & .13 \\
\hline & $p$-value & & .23 & & & .29 \\
\hline \multirow[t]{2}{*}{ Trat 5} & Correlation & & & .11 & & .28 \\
\hline & $p$-value & & & .39 & & $.02 *$ \\
\hline \multirow[t]{2}{*}{ Trat 6} & Correlation & & & .23 & & .22 \\
\hline & $p$-value & & & .06 & & .07 \\
\hline \multirow[t]{2}{*}{ Trat 7} & Correlation & & & .03 & & .03 \\
\hline & $p$-value & & & .76 & & .76 \\
\hline \multirow[t]{2}{*}{ Trat 8} & Correlation & & & & .02 & .00 \\
\hline & $p$-value & & & & .90 & .99 \\
\hline
\end{tabular}

* Correlation is significant $(\mathrm{p} \leq 0.05) \quad$ "Mean \pm Standard Deviation

Individual readiness assurance tests corresponded to practice module exercises addressing identical topics. Low to moderate correlations were observed between IRAT and practice module first attempt scores (Table 2). Statistical significance was observed 
in the correlations pertaining to the metric system $(p<.05)$, dosage calculations $(p<$ $.001)$, reducing and enlarging formulas $(p<.05)$, expressions of strength $(p<.05)$ and IV infusion and admixtures $(p<.005)$. Very low-to-low correlations were observed between TRAT scores and module first attempt scores for all lecture topics. No correlations were statistically significant.

Table 2

Correlations of IRAT and TRAT results with practice module first scores

\begin{tabular}{|c|c|c|c|c|c|c|c|c|c|}
\hline & & $\begin{array}{l}\text { Mod } 2 \\
\text { (Metric } \\
\text { System) }\end{array}$ & $\begin{array}{l}\text { Mod } 3 \\
\text { (Dose } \\
\text { Calcs.) }\end{array}$ & $\begin{array}{l}\text { Mod } 4 \\
\text { (Red. \& } \\
\text { Enl.) }\end{array}$ & $\begin{array}{l}\text { Mod 5 } \\
\text { (Spec. } \\
\text { Grav.) }\end{array}$ & $\begin{array}{l}\text { Mod 6 } \\
\text { (Express. } \\
\text { Strength) }\end{array}$ & $\begin{array}{l}\text { Mod } 7 \\
\text { (Dil. \& } \\
\text { Conc.) }\end{array}$ & $\begin{array}{l}\text { Mod } 8 \\
\text { (IV } \\
\text { Admix) }\end{array}$ & $\begin{array}{l}\text { Mod } 9 \\
\text { (Chem. } \\
\text { Equiv.) }\end{array}$ \\
\hline Irat 1 & $\begin{array}{l}\text { Correlation } \\
p \text {-value }\end{array}$ & $\begin{array}{l}.29 \\
.02 *\end{array}$ & & & & & & & \\
\hline Irat 2 & $\begin{array}{l}\text { Correlation } \\
p \text {-value }\end{array}$ & & $\begin{array}{l}.49 \\
<.0001 *\end{array}$ & & & & & & \\
\hline Irat 3 & $\begin{array}{l}\text { Correlation } \\
p \text {-value }\end{array}$ & & & $\begin{array}{l}.25 \\
.05 *\end{array}$ & & & & & \\
\hline Irat 4 & $\begin{array}{l}\text { Correlation } \\
p \text {-value }\end{array}$ & & & & $\begin{array}{l}.18 \\
.16\end{array}$ & & & & \\
\hline Irat 5 & $\begin{array}{l}\text { Correlation } \\
p \text {-value }\end{array}$ & & & & & $\begin{array}{l}.25 \\
.04 *\end{array}$ & & & \\
\hline Irat 6 & $\begin{array}{l}\text { Correlation } \\
p \text {-value }\end{array}$ & & & & & & $\begin{array}{l}.16 \\
.20\end{array}$ & & \\
\hline Irat 7 & $\begin{array}{l}\text { Correlation } \\
p \text {-value }\end{array}$ & & & & & & & $\begin{array}{l}.39 \\
.001 *\end{array}$ & \\
\hline Irat 8 & $\begin{array}{l}\text { Correlation } \\
p \text {-value }\end{array}$ & & & & & & & & $\begin{array}{l}-.06 \\
.62\end{array}$ \\
\hline $\begin{array}{l}\text { Trat } \\
1\end{array}$ & $\begin{array}{l}\text { Correlation } \\
p \text {-value }\end{array}$ & $\begin{array}{l}.17 \\
.16\end{array}$ & & & & & & & \\
\hline $\begin{array}{l}\text { Trat } \\
2\end{array}$ & $\begin{array}{l}\text { Correlation } \\
p \text {-value }\end{array}$ & & $\begin{array}{l}.23 \\
.61\end{array}$ & & & & & & \\
\hline $\begin{array}{l}\text { Trat } \\
3\end{array}$ & $\begin{array}{l}\text { Correlation } \\
p \text {-value }\end{array}$ & & & $\begin{array}{l}-.21 \\
.10\end{array}$ & & & & & \\
\hline $\begin{array}{l}\text { Trat } \\
4\end{array}$ & $\begin{array}{l}\text { Correlation } \\
p \text {-value }\end{array}$ & & & & $\begin{array}{l}-.08 \\
.54\end{array}$ & & & & \\
\hline $\begin{array}{l}\text { Trat } \\
5\end{array}$ & $\begin{array}{l}\text { Correlation } \\
p \text {-value }\end{array}$ & & & & & $\begin{array}{l}-.17 \\
.18\end{array}$ & & & \\
\hline $\begin{array}{l}\text { Trat } \\
6\end{array}$ & $\begin{array}{l}\text { Correlation } \\
p \text {-value }\end{array}$ & & & & & & $\begin{array}{l}-.05 \\
.72\end{array}$ & & \\
\hline $\begin{array}{l}\text { Trat } \\
7 \\
\end{array}$ & $\begin{array}{l}\text { Correlation } \\
p \text {-value }\end{array}$ & & & & & & & $\begin{array}{l}.02 \\
.85 \\
\end{array}$ & \\
\hline $\begin{array}{l}\text { Trat } \\
8\end{array}$ & $\begin{array}{l}\text { Correlation } \\
p \text {-value }\end{array}$ & & & & & & & & $\begin{array}{l}-.01 \\
.93\end{array}$ \\
\hline
\end{tabular}

* Correlation is significant $(\mathrm{p} \leq 0.05)$

With one exception, IRAT scores exhibited very low-to-low correlations with module high scores. A statistically significant correlation was observed between data sets pertaining to the topic of chemical equivalency $(p<.05$; Table 3$)$. Similarly, very lowto-low correlations were observed between TRAT scores and module high scores. The correlation between scores pertaining to the topic of dilution and concentration was statistically significant $(p<.05)$. 
Table 3

Correlations of IRAT and TRAT results with practice module high scores

$\begin{array}{llllllll}\text { Mod 2 } & \text { Mod 3 } & \text { Mod } & \text { Mod 5 } & \text { Mod 6 } & \text { Mod 7 } & \text { Mod 8 } & \text { Mod 9 } \\ \text { (Metric } & \text { (Dose } & 4 & \text { (Spec. } & \text { (Express. } & \text { (Dil. \& } & \text { (IV } & \text { (Chem. } \\ \text { System) } & \text { Calcs.) } & \text { (Red. } & \text { Grav.) } & \text { Strength) } & \text { Conc.) } & \text { Admix) } & \text { Equiv.) } \\ & & \& & & & & & \\ & & \text { Enl.) } & & & & & \\ & & & & & & & \end{array}$
Enl.)

\begin{tabular}{|c|c|c|c|c|c|c|c|c|}
\hline Irat 1 & $\begin{array}{l}\text { Correlation } \\
p \text {-value }\end{array}$ & $\begin{array}{l}.21 \\
.09 \\
\end{array}$ & & & & & & \\
\hline Irat 2 & $\begin{array}{l}\text { Correlation } \\
p \text {-value }\end{array}$ & & $\begin{array}{l}.06 \\
.64\end{array}$ & & & & & \\
\hline Irat 3 & $\begin{array}{l}\text { Correlation } \\
p \text {-value }\end{array}$ & & & $\begin{array}{l}.01 \\
.97 \\
\end{array}$ & & & & \\
\hline Irat 4 & $\begin{array}{l}\text { Correlation } \\
p \text {-value }\end{array}$ & & & & $\begin{array}{l}.08 \\
.53 \\
\end{array}$ & & & \\
\hline Irat 5 & $\begin{array}{l}\text { Correlation } \\
p \text {-value }\end{array}$ & & & & $\begin{array}{l}.07 \\
.61\end{array}$ & & & \\
\hline Irat 6 & $\begin{array}{l}\text { Correlation } \\
p \text {-value }\end{array}$ & & & & & $\begin{array}{l}.06 \\
.63\end{array}$ & & \\
\hline Irat 7 & $\begin{array}{l}\text { Correlation } \\
p \text {-value }\end{array}$ & & & & & & $\begin{array}{l}.23 \\
.07 \\
\end{array}$ & \\
\hline Irat 8 & $\begin{array}{l}\text { Correlation } \\
p \text {-value }\end{array}$ & & & & & & & $\begin{array}{l}.28 \\
.02 *\end{array}$ \\
\hline Trat 1 & $\begin{array}{l}\text { Correlation } \\
p \text {-value }\end{array}$ & $\begin{array}{l}.10 \\
.44\end{array}$ & & & & & & \\
\hline Trat 2 & $\begin{array}{l}\text { Correlation } \\
p \text {-value }\end{array}$ & & $\begin{array}{l}.03 \\
.84\end{array}$ & & & & & \\
\hline Trat 3 & $\begin{array}{l}\text { Correlation } \\
p \text {-value }\end{array}$ & & & $\begin{array}{l}-.03 \\
.84\end{array}$ & & & & \\
\hline Trat 4 & $\begin{array}{l}\text { Correlation } \\
p \text {-value }\end{array}$ & & & & $\begin{array}{l}.18 \\
.15 \\
\end{array}$ & & & \\
\hline Trat 5 & $\begin{array}{l}\text { Correlation } \\
p \text {-value }\end{array}$ & & & & $\begin{array}{l}.19 \\
.12\end{array}$ & & & \\
\hline Trat 6 & $\begin{array}{l}\text { Correlation } \\
p \text {-value }\end{array}$ & & & & & $\begin{array}{l}.32 \\
.01 *\end{array}$ & & \\
\hline Trat 7 & $\begin{array}{l}\text { Correlation } \\
p \text {-value }\end{array}$ & & & & & & $\begin{array}{l}-.09 \\
.36\end{array}$ & \\
\hline Trat 8 & $\begin{array}{l}\text { Correlation } \\
p \text {-value }\end{array}$ & & & & & & & $\begin{array}{l}.19 \\
.13\end{array}$ \\
\hline
\end{tabular}

* Correlation is significant $(\mathrm{p} \leq 0.05)$

Figures 1 and 2 are scatterplot displays of the trends by which mean IRAT and TRAT scores are associated with comprehensive final exam performances. The plots indicated stronger association between IRAT performance and final exam performance when compared to the association between TRAT performance and final exam performance. The contrast in scatterplot shape was representative of the poorer correlation seen among TRAT and assessment scores in general. 


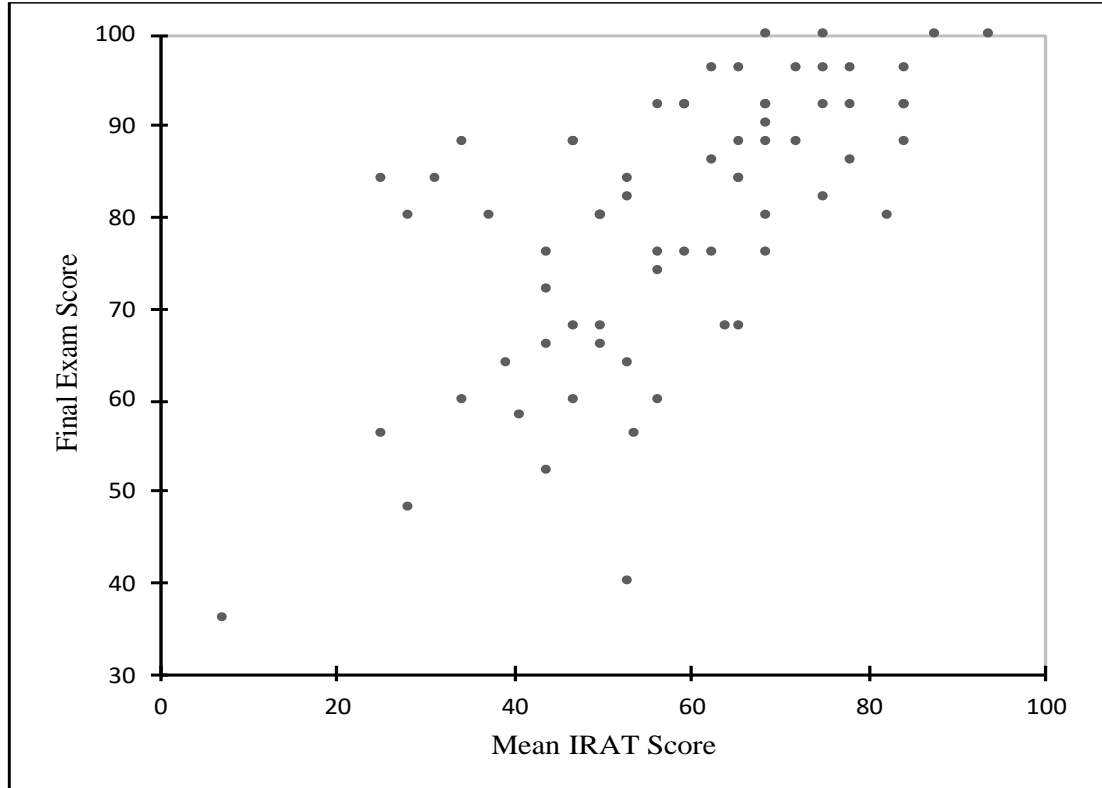

Figure 1

Scatterplot of students' final exam scores vs. Mean IRAT scores

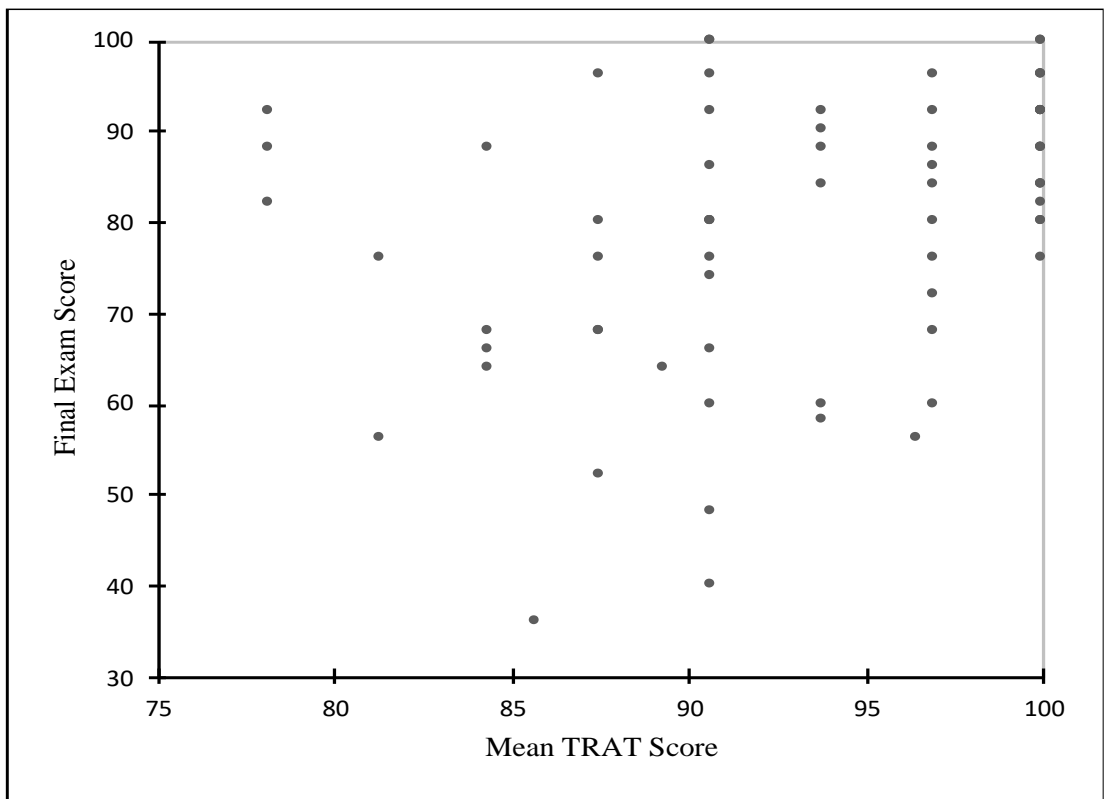

Figure 2

Scatterplot of students' final exam scores vs. Mean TRAT scores 


\section{DISCUSSION}

Although moderate in magnitude, the correlation effect sizes and statistical significance between IRAT scores and lecture assessment scores are distinctive. The results are intuitive, given that RAT and lecture assessments were similarly structured. Both sets of assessments were proctored and timed. In addition, the rigor of questions presented during the assurance tests was similar to lecture assessments. In essence, IRAT exercises served as a prelude to subsequent assessments in the lecture course. The relationship between TRAT scores and lecture assessments dramatically differ from aforementioned IRAT correlations, due to substantial improvements in score performances that are characteristic of TRAT treatments. The lower correlations associated with TRAT scores are perhaps indicative of team performances masking individuals' understanding of topics at the time of the team encounter. Students' IRAT scores were consistently poorer than TRAT scores, alluding to the beneficial nature of team collaboration to TRAT performance.

Individual readiness assurance test scores better correlate to lecture assessment and first attempt online module scores than TRAT scores correlate to these performances. The highest correlations are observed between IRAT scores and lecture exams, especially those pertaining to the topics of expressions of strength, metric system and unit conversions, and dose calculations. The results infer that IRAT participation may benefit students' short-term preparation for major assessments. Furthermore, IRAT scores better correlate with lecture assessment scores than with practice module first attempt scores. Although modules were made available to students at approximately the same times that RAT assessments were encountered, students were free to commence modules any time prior to the end of the semester. Some students began working on the modules on the date of release or (shortly thereafter), while other students opted to wait several weeks before starting exercises. In addition, IRAT exercises were attempted under the duress of controlled conditions. This contrasted with untimed, un-proctored module conditions, which might account for the difference seen in IRAT correlation results.

Neither assurance test distinguishes itself from the other when correlated with module high scores. The lone instances of low-to-moderate correlation of assurance test scores with module high scores pertain to the topics of chemical equivalency and intravenous admixtures. Students have historically experienced difficulties with these topics, which are introduced in the latter stages of the course. Students have also historically exhibited substantial variation in performance on all lecture assessments aside from the comprehensive final exam. Decreased mean scores and increased standard deviations were observed in Exam 3 and the chemical equivalency quiz compared to other major assessments, indicative of the difficulties students experience with these topics. Perhaps these isolated instances of increased RAT correlation with module high score can be attributed to the challenge of these concepts.

Statistical significance associated with moderate correlations amongst comparisons is intriguing. Statistical significance is limited in discerning the extent to which data differences are meaningful (Harlow et al., 1997). Given that the sample size is not especially large, the low $p$-values are a plausible function of effect sizes. Nonetheless, 
the $p$-values provide a measure of certainty regarding the nature of assessment correlations. Interpretations of r-correlations differ among disciplines, particularly with respect meaningful outcomes. Akoglu (2018) noted that moderate r-correlations in one discipline are considered more impactful in other disciplines in some instances. In contrast to a discipline such as psychology, of which there exists a century's worth of correlation reporting with well-established contexts, correlation data in pharmacy calculations is not as extensive. Educational studies pertaining to student achievement have earned a reputation for yielding small effect sizes, including correlation measurements (Coe, 2002). It is possible that the correlations observed meaningfully exemplify this trend.

Applications of the RAT have been sparingly reported for pharmacy calculations. Mastropietro and colleagues (2019) reported significant improvements in calculations students' TRAT scores in comparison to their IRAT scores. Wara and colleagues (2019) also reported use of RAT scores pertaining to pharmacy calculations, but assessment of quantitative ability was not the focus of the activity. However, RAT correlation data has been reported in medical and other pharmacy disciplines. For instance, significant correlations (Collins et al., 2019) and low-to-moderate correlations have been noted between IRAT scores and exam outcomes in medical students (Carrasco et al., 2019). Positive correlations have also been reported between RAT scores and learning outcomes in pharmacy students (Malhotra, 2019; Persky \& Pollack, 2011). At minimum, RAT interventions might serve as harbingers of performance outcomes on subsequent major assessments. The noticeable contrast in correlation graph shapes between Figures 1 and 2 suggests IRAT exposure to predictive of final exam performance, at least to an extent. In addition, improved performance on the comprehensive final examination in comparison to prior assessments implies RAT to be valuable to students' preparation. The IRAT in particular appears to have been a useful way for students to practice under exam conditions, which might have assisted them in the long run.

\section{Limitations}

There were limitations to the study. The assessments of 69 students were analyzed in the investigation, so statistical power might have impacted tests of significance. An ideal experimental design would feature a power analysis prior to the commencement of data collection. This is difficult in an enrollment-dependent setting. Although students' (verbal) feedback about their RAT experiences was mostly positive, no formal survey data was collected from students to gauge their opinions of the intervention. Furthermore, the number of calculations problems encountered during each RAT session (8) was a fraction of the number of problems encountered on lecture assessments covering identical topics. Future investigations pertaining to RAT in pharmacy calculations would benefit from formal collection of student feedback, and from standardization of assessment conditions and characteristics.

\section{CONCLUSION}

Although TBL and RAT interventions have been used liberally in health education, there have been relatively few reports of its use in teaching the subject of pharmacy 
calculations. This study yielded low to moderate positive correlations between pharmacy calculations students' IRAT scores and their conventional assessment scores. Students' IRAT performances were also encouragingly predictive of their comprehensive final exam performances. In contrast, TRAT correlations were predominately lower in magnitude. Readiness assurance test results, particularly IRAT scores, may be associated with students' performances on subsequent assessments in pharmacy calculations. The usefulness of RAT intervention within pharmacy calculation warrants further inquiry.

\section{REFERENCES}

Akoglu, H. (2018). User's guide to correlation coefficients. Turkish Journal of Emergency Medicine, 18(3), 91-93. https://doi: 10.1016/j.tjem.2018.08.001.

Anderson, H. G., Frazier, L., Anderson, S. L., Stanton, R., Gillette, C., Broedel-Zaugg, K., \& Yingling, K. (2017). Comparison of pharmaceutical calculations learning outcomes achieved within a traditional lecture or flipped classroom andragogy. American journal of pharmaceutical education,81(4). https://doi: 10.5688/ajpe81470.

Bauler, T. J., Sheakley, M. L., \& Ho, A. (2020). Use of the team-based learning readiness assessment test as a low-stakes weekly summative assessment to promote spttpsaced and retrieval-based learning. Medical Science Educator, 30(1), 605-608. https://doi.org/10.1007/s40670-019-00826-x.

Bell, E. C., Fike, D. S., Liang, D., Lockman, P. R., \& McCall, K. L. (2017). Assessment of computer-mediated module intervention in a pharmacy calculations course. Education and Information Technologies, 22(5), 2013-2025. https://doi.org/10.1007/s10639-016-9531-8.

Burgess, A., Bleasel, J., Haq, I., Roberts, C., Garsia, R., Robertson, T., \& Mellis, C. (2017). Team-based learning (TBL) in the medical curriculum: better than PBL? BMC Medical Education, 17(1), 1-11. https://doi.org/10.1186/s12909-017-1068-z.

Burns, M., Pierson, E., \& Reddy, S. (2014). Working Together: How Teachers Teach and Students Learn in Collaborative Learning Environments. International Journal of Instruction, 7(1), 17-32.

Carrasco, G. A., Behling, K. C., \& Lopez, O. J. (2019). First year medical student performance on weekly team-based learning exercises in an infectious diseases course: insights from top performers and struggling students. BMC Medical Education, 19(1), 15. https://doi.org/10.1186/s12909-019-1608-9.

Coe, R. (2002, September). It's the effect size, stupid. In Paper presented at the British Educational Research Association annual conference (Vol. 12, p. 14).

Collins, C. M., Carrasco, G. A., \& Lopez, O. J. (2019). Participation in active learning correlates to higher female performance in a pipeline course for underrepresented 
students in medicine. Medical Science Educator, 29(4), 1175-1178. https://doi.org/10.1007/s40670-019-00794-2.

Davies, M., Pon, D., \& Garavalia, L. S. (2018). Improving pharmacy calculations using an instructional design model. American journal of pharmaceutical education, 82(2). https://doi.org/10.5688/ajpe6200.

Harlow, L.L., Mulaik, S.A., \& Steiger, J.H., (1997). What if there were no significance tests? Mahwah, NJ: Lawrence Erlbaum Associates Publishers.

Hashim, H., Ali, M. N., \& Samsudin, M. A. (2018). Nurturing Habits of Mind (HOM) Through Thinking Based Learning (TBL) in Doing Science Technology, Engineering and Mathematics (STEM) Project. EDUCATUM Journal of Science, Mathematics and Technology, 5(2), 7-18.

Hegener, M. A., Buring, S. M., \& Papas, E. (2013). Impact of a required pharmaceutical calculations course on mathematics ability and knowledge retention. American journal of pharmaceutical education, 77(6). https://doi.org/10.5688/ajpe776124.

Hincapie, A. L., Cutler, T. W., \& Fingado, A. R. (2016). Incorporating health information technology and pharmacy informatics in a pharmacy professional didactic curriculum-with a team-based learning approach. American journal of pharmaceutical education, 80(6). https://doi.org/10.5688/ajpe806107.

Koh, Y. Y. J., Rotgans, J. I., Rajalingam, P., Gagnon, P., Low-Beer, N., \& Schmidt, H. G. (2019). Effects of graded versus ungraded individual readiness assurance scores in team-based learning: a quasi-experimental study. Advances in Health Sciences Education, 24(3), 477-488. https://doi.org/10.1007/s10459-019-09878-5.

Kolluru, S., Roesch, D. M., \& de la Fuente, A. A. (2012). A multi-instructor, teambased, active-learning exercise to integrate basic and clinical sciences content. American journal of pharmaceutical education, 76(2). https://doi.org/10.5688/ajpe76233.

Lacroix, M., McCall III, K. L., \& Fike, D. S. (2014). The Keller personalized system of instruction in a pharmacy calculations course: a randomized trial. Currents in Pharmacy Teaching and Learning, 6(3), 348-352. https://doi.org/10.1016/j.cptl.2014.02.002.

Letassy, N. A., Fugate, S. E., Medina, M. S., Stroup, J. S., \& Britton, M. L. (2008). Using team-based learning in an endocrine module taught across two campuses. American journal of pharmaceutical education, 72(5). https://doi.org/10.5688/aj7205103.

Malhotra, A. (2019). Enhancing Team-based Learning of Pharmacology Using Technology-assisted Prerequisite Content Preparation. The FASEB Journal, 33(S1), 803-807. https://doi.org/10.1096/fasebj.2019.33.1_supplement.803.7

Mastropietro, D., Singh-Franco, D., Leonard, S., \& Dressler, M. D. (2019). Evaluation of a Compressed Pharmaceutical Calculations Course in First-Year Pharmacy Students. American journal of pharmaceutical education, 83(5). https://www.ajpe.org/doi/full/10.5688/ajpe7654. 
Naughton, L., Butler, R., Parkes, A., Wilson, P., \& Gascoyne, A. (2020). Raising aspirations using elements of team-based learning in mathematics: a pilot study. International Journal of Mathematical Education in Science and Technology, 117.

Nutan, M. T., \& Demps, E. L. (2014). Online assessments in pharmaceutical calculations for enhancing feedback and practice opportunities. Currents in Pharmacy Teaching and Learning, 6(6), 807-814. https://doi.org/10.1016/j.cptl.2014.07.010.

Orr, K. K., Feret, B. M., Lemay, V. A., Cohen, L. B., Mac Donnell, C. P., Seeram, N., \& Hume, A. L. (2015). Assessment of a hybrid team-based learning (TBL) format in a required self-care course. Currents in Pharmacy Teaching and Learning, 7(4), 470-475. https://doi.org/10.1016/j.cptl.2015.04.016.

Parmelee, D., Michaelsen, L. K., Cook, S., \& Hudes, P. D. (2012). Team-based learning: a practical guide: AMEE guide no. 65. Medical Teacher, 34(5), e275-e287. https://doi.org/10.3109/0142159X.2012.651179.

Paterson, J., Sheryn, L., \& Sneddon, J. (2013, February). Student responses to teambased learning in tertiary mathematics courses. In In proceedings of 15th annual conference on research in undergraduate mathematics education (Vol. 2, pp. 619-626).

Persky, A. M. (2012). The impact of team-based learning on a foundational pharmacokinetics course. American journal of pharmaceutical education, 76(2). https://doi.org/10.5688/ajpe76231.

Persky, A. M., \& Pollack, G. M. (2011). A modified team-based learning physiology course. American journal of pharmaceutical education, 75(10). https://doi.org/10.5688/ajpe7510204.

Shaikh, A.A., Raihan Sajid, M., Hasanein, H.S., \& Yaqinuddin, A. (2017). Audience Response System (Clickers) in Team Based Learning: The Good, the Bad and the Feedback. Austin Journal of Anatomy. 4(2).

Wara, B., Daly, J., Morrissey, H., \& Ball, P. (2019). A study to explore learning style preferences of pharmacy students with regard to pharmaceutical calculations. International Journal of Current Pharmaceutical Research. 11(4), 88-96. https://doi.org/10.22159/ijcpr.2019v11i4.34933.

Warsah, I., Morganna, R., Uyun, M., \& Afandi, M. (2021). The Impact of Collaborative Learning on Learners' Critical Thinking Skills. International Journal of Instruction, 14(2), 443-460.

Wilson, J. A., Waghel, R. C., \& Dinkins, M. M. (2019). Flipped classroom versus a didactic method with active learning in a modified team-based learning self-care pharmacotherapy course. Currents in Pharmacy Teaching and Learning, 11(12), 12871295. https://doi.org/10.1016/j.cptl.2019.09.017. 
Yaacob, A., Mohd Asraf, R., Hussain, R. M. R. \& Ismail, S. N. (2021). Empowering Learners' Reflective Thinking through Collaborative Reflective Learning. International Journal of Instruction, 14(1), 709-726. https://doi.org/10.29333/iji.2021.14143a

Zingone, M. M., Franks, A. S., Guirguis, A. B., George, C. M., Howard-Thompson, A., $\&$ Heidel, R. E. (2010). Comparing team-based and mixed active-learning methods in an ambulatory care elective course. American journal of pharmaceutical education, 74(9). https://doi.org/10.5688/aj7409160. 